\title{
Unusual Fingers
}

\section{Scientific Studies of Sexual Orientation}

\author{
LYNDA BIRKE
}

Animal models have indicated that [hormones] acting before birth might influence the sexual orientation of adult humans ... we examine the ... pattern of finger lengths, and find evidence that homosexual women are exposed to more prenatal androgen than heterosexual women are; also, men with more than one older brother, who are more likely than first-born males to be homosexual in adulthood, are exposed to more prenatal androgen than eldest sons. (Williams et al., 2000: 455)

some scientists have begun to view both heterosexuality and homosexuality as natural variations of the human condition that are at least as deeply rooted in nature as in nurture. (Hamer and Copeland, 1994: 20)

Questions about the origins of homosexuality would be of little interest if it were not a stigmatized behavior. We do not ask comparable questions about 'normal' sexual preferences, such as preferences for certain physical types or for specific sexual acts that are common among heterosexuals. (Hubbard and Wald, 1993: 95)

Gay genes, different length fingers - the biology of homosexuality seems to be rather newsworthy. What science has to say about who we are may seem quite distant from our everyday lives. But it matters profoundly because not only does science seek to define how we came to be as we are, but it has also offered attempts at cures aimed at eradicating homosexuality.

If homosexuality is indeed just another 'natural' variation of sexuality, then it may be reasonable for scientists to study how it develops - as the quote from Hamer and Copeland suggests. They might then look for a gene which seems to predispose a man to be gay, or ask whether lesbians have been exposed to high levels of the hormones called androgens. But whether or not it is 'natural', homosexuality has also been stigmatized behaviour; indeed, all non-procreative sexual practices are condemned and vilified by some people. That social/cultural context profoundly influences the choices scientists make to study one phenomenon rather than another: it is 'deviant' sexualities, not heterosexuality, which is called into question.

My aim in this chapter is to sketch out some of the ways in which science has dealt with the idea of homosexuality. 'Science' (by which I mean the natural sciences, notably biology in this context) is a word we 
usually take to mean the study of the natural world; it includes, among other things, certain methods, devices and narratives which help to give it its authoritativeness. Thus, to say that something is scientific is to give it great significance in our culture; we believe something more easily if there seems to be 'objective proof'.

Yet whatever its claim to objectivity, science is not neutral; its practitioners live in a particular historical period, in a particular culture. That history and culture influence how they generate hypotheses, how they interpret data, and whether and how they obtain funding or publication. Thus, in a climate in which massive international funding goes to 'mapping' genomes and moving bits of DNA around, 'the' gene has become such a powerful cultural icon (Nelkin and Lindee, 1995); it is then hardly surprising that geneticists search for all kinds of genes - including those putatively determining our sexuality.

Throughout this chapter, therefore, I try to locate ideas in their social and cultural context. Although I outline various theories about the biological bases of homosexuality, I argue that there is little evidence of any such biology. But that is not to say that our biology is never involved in our sexuality (which, after all, is often expressed through our biological bodies); rather, we have yet to find ways of talking about biology and sexuality that are liberatory and not determining.

Among other things, biomedicine has drawn heavily on cultural stereotypes of homosexuality that collapse sexual orientation and behaviour onto stereotypic notions of gender division. On the whole, the scientific literature is concerned with what makes someone $a$ homosexual; and not just a homosexual, but a gender-stereotyped one. So, the personae of the scientific stories are the effeminate gay man and the butch lesbian. Thus, the scientists reporting on finger length started from the assumption that lesbians had been masculinised by hormones in the womb. What these stereotyped characters actually do is not at issue; it is their (our) lesbian/gay identities, their essences, that matter.
Michele Ana Barale has written that 'heterosexuality ... seeks to create lesbians whose desires are as apprehensible as its own ... the lesbian body itself is made the site for such self-depiction' (Barale, 1991: 237). Science lends authority to such recreation, telling tales of homosexual desire as a reflection of heterosexual desire, but a desire in which something is amiss. Thus, in many scientific narratives, lesbian desire is understood in terms of masculinity, and markers of such masculinity have been sought in lesbians' biological bodies.

Both heterosexuality and masculinity are the dominant narratives in scientific tales (Butler, 1993; Fausto-Sterling, 1997). That is one reason why the question, 'what makes us gay?' can be asked; for we are the other to the heterosexual norm. Without that binary opposition between heterosexual and homosexual, the question would have little meaning. Thus, scientific stories seek out that which is amiss with the lesbian/gay body - what is 'other' about it - be that parts of the brain or parts of the chromosomes.

These are the reasons why I write primarily about homosexuality rather than drawing on more recent concepts of queer, which have little or no parallel in biomedical discourse. Here, the division is usually simply hetero/homosexual, male/female. While some areas of science have recognised greater diversity (sexology, for example, has historically tried to map out sexual diversity), the search for biological causes of sexual variation has been mired in dichotomies. Nature, it would seem (or at least as it is described by many scientists) has no space for gender as performance, or as multiple (see Butler, 1993).

Despite newer ideas about sexualities and multiplicity in the wider culture, however, there has been a recent upsurge of interest in biological bases of homosexuality, but why now? Addressing these questions raises, I would argue, crucial issues for lesbian and gay studies; although our academic inquiry has included discussion of essentialism (Fuss, 1989; Stein, 1992), we have directly addressed science and its claims much less 
often. Given the hegemony of the "new genetics', we need to know whether claims about 'gay genes' really help to reduce discrimination against us, as some have argued. Or do such claims merely reinforce the same, tired, old prejudices? And, if we find fault with them, is simply rejecting or ignoring biology the only answer? Could lesbian/gay studies benefit from a less polarised view of the place of biology? These are themes that I want to draw out in this chapter.

\section{SCIENCE ... IN CONTEXT}

Before going into details of scientific theories, however, I want to ask a few questions about science. Science has enormous authority; within Western culture, we are more likely to believe claims if they are 'scientific' than if they derive from other frameworks. That is why recent claims about putative 'gay brains' or 'gay genes' are so significant: they were claims made by scientists and published in prestigious journals. As a result, they were widely heralded in the media, which further enhances scientific authoritativeness, ${ }^{1}$ headlines typically emphasise that 'scientists have found such-andsuch', thus reinforcing the notion that what science creates is certainty. When researchers at the National Institutes of Health in the USA located a gene associated with increased male-to-male courtship among Drosophila flies, it was reported as a 'gay gene' in fruit flies (e.g. Highfield, 1995). No matter that this has nothing to do with humans, the headline implies a similar genetic mechanism to that claimed for gay men: 'the' gay gene.

Part of the process of doing science is to construct persuasive arguments. It is not enough just to do the experiments. You must also persuade other scientists (perhaps especially those opposed to your views), as well as people outside the labs. Science is, among other things, a form of rhetoric (Gross, 1990). To persuade requires constructing written and verbal forms that, basically, deflect any potential counterclaims (Latour, 1987).
In addition, scientific arguments rely on material produced by apparatus in the labs what Bruno Latour (1987) calls the output from inscription devices. To be persuasive, a scientist must draw on tables, graphs, and so on, from some device set up to measure something. Merely observing that' $\mathrm{x}$ affects $\mathrm{y}$ is not enough - you have to demonstrate it quantitatively through graphs: indeed, laboratory work is largely organised around ways of " framing" a phenomenon so that it can be measured and mathematically described' (Lynch, 1990: 170, emphasis in original). In other words, what actually happens in laboratories is not only observation of 'nature' (if, indeed, it is nature once inside the lab: Knorr-Cetina, 1983) but also practices which set up 'nature' in measurable ways.

Scientists, moreover, must learn not only to produce such inscriptions, but also to read them. Learning to 'read' nature through apparatus is a central part of scientific training. You have to learn how to see down a microscope, for instance, and how to interpret what you see - even if all you actually see at first is a reflection of your own eyeball (Keller, 1996). In learning to read scientific diagrams, you must learn to generalise from the specific (the particular tissue you see under the microscope, say) to the general (a diagram of 'the' ovary, for example). I am stressing these themes from recent sociological studies of science because they are relevant to thinking about biology and homosexuality. How we learn to read scientific images matters when the paper in question shows us photographs of, say, 'gay brains'. What is it that we are seeing? What does it do to label the fuzzy lines on a photograph as representing 'gay brains'? What has gone into the production of this photograph, and to whom is it directed?

Historically, scientific arguments about homosexuality have assumed that it is a problem whose origins need to be understood. Such assumptions have helped both to 'frame the phenomenon', and to define homosexual behaviour as 'unnatural'. That 
homosexuality has largely meant stigmatised behaviours contributed to the selling power of the arguments; on the whole, the history of science's involvement in lesbian and gay lives has been a sorry one.

A crucial step in scientific involvement was the development of 'the homosexual' as a specific kind of person (by contrast to homosexual behaviour, which anyone could engage in). Ideas about 'the' homosexual developed particularly during the nineteenth century, alongside theories of evolution, thus setting the scene for speculation about what might cause a person to become lesbian or gay.

Biological theories about homosexuality waxed and waned during the twentieth century. Once identified in the early decades of the century, the 'sex hormones' for example became a focus for several decades. These are the hormones produced by the gonads ovaries and testes - and which bring about the secondary sexual characteristics at puberty: were these, scientists wondered, the cause of deviant sexualities? But whatever the explanatory potential of these theories, they also contributed to various attempts to use hormones to 'cure' homosexuals of their deviant behaviour (alongside other interventions, including surgery).

Such ideas became less prominent in the wake of the women's and gay liberation movements in the 1970s. Now, there was more emphasis on the ways in which sexuality and gender might be socially constructed. But however useful this move was in counteracting earlier medical abuses, it also allowed anti-gay campaigners to argue that, if it were not 'natural', then we could all just stop sinning and become happy heterosexuals.

That reaction helped to usher in a third phase of scientific theories. Over the last decade, various attempts have been made (often by gay scientists) to trace some biological basis. Brains and genes, rather than hormones, are now explicitly the focus. The recent surge of writing about the putative genetics of homosexuality rests, inevitably, upon the dramatic development - and power - of the new genetics (Terry, 1997: 288). Through genetic manipulation, 'nature' now offers the prospect of manipulating organisms, of changing their genetic potential. In that sense, Terry suggests, nature and science may seem to be more liberating to some scientists than nurture which may be 'imagined as hostile, hopeless and homophobic' (ibid.: 289).

Underlying these recent claims about gay genes or gay brains (and 'gay' here usually means male homosexuality; lesbians, perhaps fortunately, are typically missing from these accounts) is the belief that homosexuality is, indeed, natural. If it occurs as a variant of brain structure, if the gene can be demonstrated within the variations of the human genome, if homosexual behaviour can be demonstrated in other animal societies, then it occurs 'within nature' and should be accepted as such, advocates believe.

Yet what is 'natural'? Much of the literature searching biological correlates of sexuality assumes that demonstrating a biological link means that 'deviant' sexuality becomes 'natural'. I am always suspicious of this word, 'natural', which covers up a great deal. Does natural mean good, as in so many advertisements for different kinds of food? Does natural imply normal, which can convey both statistical and moral overtones? Or does it mean something that is in 'Nature' with connotations of separation of nature from culture? ${ }^{2}$

One problem with invoking nature is that it frequently implies biological determinism that is, the notion that some aspects of a person's behaviour are somehow rooted in caused directly by - their biology. This concerns me because biological determinism tends to arise in arguments defending rigid, traditional roles of gender and sexuality the kind of rigidity that feminists and others have fought for so long. We all know the kind of thing: hormones that predispose the females among us to the ironing board, or males to the company board. ${ }^{3}$

Apart from my being hostile to such claims for political reasons, they also concern me because of the practical consequences 
that have followed in the past from such beliefs, such as, for example, attempts to 'cure' homosexuality. I see no reason to be complacent now, or to assume that there will be no more such attempts in the future. I will return to the critiques of biologically determinist ideas later in the chapter, after considering the scientific theories in more detail.

\section{SCIENTIFIC STORIES}

There are, inevitably, many interconnecting threads within the various stories science tells about sexuality. To follow them, I want to separate them out into two parts. I do so because they draw on slightly different theories and assumptions; there is, however, a great deal of overlap. One thread follows the story of the sex hormones - from their initial discovery and their mapping onto sex/gender to their links with the organisation of the brain. Here, we find stereotypes of gender divisions re-emerging into molecules; no matter that hormones are just molecules, biomedical stories have allocated them gender: androgens are now routinely referred to as 'male' hormones even though we all produce them (Spanier, 1995). We can find assumptions of 'natural' behaviours allegedly allocated, of course, to one or the other sex. So, mounting behaviour by a rat is portrayed as masculine and heterosexual, even though females often do it too. We also encounter the mapping of what might be termed the 'homosexual body', defined as measurably different from its heterosexual counterpart (Terry, 1999).

The second thread follows stories of genes and evolution. Here, theories usually assume that the highest aim of organisms is reproduction; individuals must spread their genes around by reproducing. So, the question arises: how did homosexuality (assumed not to lead to many offspring) evolve? Why do the putative genes for it persist? And if they exist, can they be found in other kinds of animals? Again, these questions make assumptions about what constitutes 'natural' behaviours, but they also suggest natural types - those who possess certain genes. Here, it is not the body (as we perceive it) that is directly being mapped, but the hidden codes of DNA that helped to create it. These reified bits of DNA acquire characteristics - the gay gene, the gene for learning disabilities-that can be passed on to any offspring we may have.

\section{THE HORMONAL IMPERATIVE}

The notion of homosexuals as a 'third sex', intermediate between men and women, was mooted in the late nineteenth century. It is usually attributed to Karl Ulrichs, who sought greater acceptance for homosexuals like himself, through his emphasis on the homosexual person rather than practices, and based his theory on study of hermaphrodites (Kennedy, 1997). To Ulrichs, being attracted to men indicated a female psyche; so, he hypothesised, homosexual men may have a male body, but the mind of a woman. This notion - that sexuality must be either female or male - has persisted. It surfaces in the feelings expressed by many people seeking transsexual transformation, because they feel that their psyches are trapped in the wrong (i.e. of the 'other' sex) body. It surfaces, too, in scientific theories about sexuality and gender.

During the early years of the twentieth century, the search for biological markers of homosexuality focused on external anatomy. This was framed within the normative assumption of two sexes; thus, doctors sought indicators of 'mannishness' in lesbians, such as an enlarged clitoris, ${ }^{4}$ or evidence that gay men were physically effeminate (Gibson, 1997; Terry, 1999). The equation is a simple and all too familiar one: to be gay/lesbian is to be partly the 'other' sex. ${ }^{5}$

Running parallel to this search for anatomical markers was the discovery of the steroid sex hormones in the early twentieth century (Hall, 1975; Fausto-Sterling, 2000). 
The significance of the gonads (ovaries and testes) had been known for some timeanimals, after all, were routinely castrated and the consequent behavioural changes known. But once scientists had identified the steroid hormones, it became possible to attach specific molecules to the actions of the gonads. The steroid hormones, produced by ovaries, testes and adrenals, are androgens (hormones such as testosterone), oestrogens (e.g. oestradiol) and progestins (e.g. progesterone). What differentiates men and women is the average amounts of each kind produced; there is no absolute difference.

Despite that, these molecules were quickly labelled as gendered-names that are with us still, as we habitually refer to 'male' or 'female' hormones (Oudshoorn, 1994; Wijngaard, 1997). That these hormones were characterised as strictly dualistic is not, perhaps, surprising; there has been a long history of reading gender (and other) stereotypes onto nature - molecules are no exception (Schiebinger, 1994; Spanier, 1995). ${ }^{6}$ Steroid hormones were being named, moreover, at a time of much debate about the status of women, and of feminist challenges to gender stereotypes (Rosenberg, 1982; Fausto-Sterling, 2000). Although scientists were forced, by the 1930 s, to recognise that the steroids did not map quite so easily onto two sexes as they had previously thought, ${ }^{7}$ the legacy of the binary division remains.

The locus of gendered dualism has shifted, however, from the gonads to the brain. That is, where previously, scientists sought direct causes in hormones produced by adult gonads, they now focus attention on indirect effects before birth. From the 1960 s on, scientists have focused on the idea that hormones affect the brain long before the foetus is born, bringing about permanent structural change. And once changed, the brain itself can be 'masculine' or 'feminine' in its response during adulthood to circulating hormones, according to this hypothesis of brain organisation. In studies of laboratory animals, scientists might measure this by measuring the kind of behaviour the animal shows when it is adult (assuming that behaviour can reliably be designated as masculine or feminine ${ }^{8}$ ).

Part of the context in which the shift to organisation theory took place was the rapid post-war development of ideas borrowed from control systems. Bodies became increasingly portrayed as elaborate machines, their internal processes as tightly controlled systems (see Birke, 1999). The endocrine system was no exception; feedback controls the output of ovaries and testes, via the brain and its own hormones. That is, hormones produced by the gonads (ovaries or testes) are carried by the blood to the brain; there, they influence (feed back) the output of the brain's own hormones, from the hypothalamus. These in turn control the amount of hormones produced by the gonads. It is a self-controlling 'system'. This emphasis on feedback systems implies that deviation from a particular point must be corrected (so allowing for possibilities of external control, through drugs). ${ }^{9}$ It also shifted the focus of attention onto the brain, as the organ controlling the whole system.

So, sex hormones in the rest of the body became less important than prenatal organisation of the brain by sex hormones for theorists of how gender develops. I say gender here, because that was indeed the primary focus-how we become male or female. How we become gay or straight was, as usual, seen as a product of that initial dichotomy. Given the way that gender duality is so often confounded with sexual orientation, it was perhaps inevitable that the idea of hormonal differentiation of the brain would be extrapolated to homosexuality. If brains of men and women differ, the reasoning goes, then so might the brains of homo- and heterosexual folk.

One example of such thinking was Simon LeVay's much publicised claim to have identified 'gay brains' (LeVay, 1991). More precisely, he claimed that he had found differences in a small area of the brain between straight and gay men.

Central to LeVay's claims is the organisation hypothesis-the belief that the brain 
has been permanently reorganised by sex hormones prior to birth, in ways that will later determine the person's sexual orientation. In the case of gay men, the bit of the brain allegedly involved was smaller than its equivalent in straight men; this area is a small nucleus, the INAH $3,{ }^{10}$ of the hypothalamus at the base of the brain. LeVay put the claims more graphically in a later book, when he suggested that gay men simply donot have the brains for straight sex (LeVay, 1993).

The assumptions underlying these claims are unsurprising. First, LeVay starts from the premise that the part of the hypothalamus he studied is involved in sexual orientation, on the basis of other experiments in which the mounting behaviour of rats was altered by damage to similar areas, indicating some scientists believed-that the animals' sexuality was affected. Second, he refers to claims that parts of the INAH are smaller in women than men (although studies looking at the INAH have reported contradictory results). Third, his study supposes that it is logical to move from these claims to homosexuality. The logic runs thus: gay men and heterosexual women have in common that they are attracted to men. So, he reasoned, perhaps there was something similar between them in the way that their brains have developed.

There are many problems with this line of thought. For a start, the relationship between human sexuality, sexual orientation and gender is immensely complex, involving multiple cultural responses to particular situations. That is partly why some feminist authors have insisted on viewing gender as performance (e.g. Butler, 1993). Gender and sexuality are not something given but are constantly being acted out, performed, recreated. So, what is it that LeVay might be measuring when he says that there are differences in the hypothalamus related to sexual orientation?

It is also notoriously difficult to extrapolate from data from laboratory animals. ${ }^{11}$ Interfering with the hormone levels of prenatal or infant rats does alter their later behaviour. Blocking androgens ('male' hormones) in male baby rats makes them less likely to mount (defined as male behaviour) when they are adults. According to some authors (e.g. Dorner, 1976), these interventions created a homosexual rat, because these animals were willing to accept the advances of other males - as does a female in oestrus. ${ }^{12}$

Now the problems, in turn, with that are the underlying assumptions. These are (i) that it is quite simple behaviourally to distinguish 'male' and 'female' behaviour. But, with the possible exception of the physical act of putting a penis into a vagina, there are no behaviours which are the preserve of only one sex. (ii) That homosexual behaviours never occur among non-human animals (also a dubious assumption); and (iii) that only the rat accepting the mounting (femalelike) was homosexual. Curiously, Dorner never used the word homosexual to describe the other (male) rat who did the mounting. Possibly that was the rat equivalent of the married man who goes cottaging then denies vociferously any homosexual tendencies.

Even if different studies did agree that there was a consistent difference between the brains of gay and straight people (and even if we could be sure that such pure types of people exist ${ }^{13}$ ), then what does it mean? The brain is a highly complex and malleable organ, responding continually to change. Any possible difference might just as well be the product of rather different lifestyles (in the case of the LeVay study, many critics pointed to the fact that the brains he obtained from gay men were from men who died of AIDS, which may well have influenced the brain). Or it might have something to do with preferred sexual practices, not sexual orientation per se. Or, it might have something to do with the type of partner (not his/her sex): facetiously we might ask whether there is a bit of the brain associated with falling for people with blond hair, or large biceps, or a preference for leather.

Just what are scientists measuring when they search for biological bases? They may 
locate differences in the gross structure of the brain. But differences with respect to what? Any difference in size of particular structures between one brain and another is not of interest unless those differences can be made to mean something. That is, the brains have to be given meaning through being allocated to particular categories categories which in turn have meaning within a particular culture. Just as, in the nineteenth century, brain size and shape were linked to race and gender (Genova, 1989), now gender and sexuality are mapped onto specific areas of the brain because these are significant social categories. There is much less invested culturally in whether your preferences are for large biceps than there is in whether you are gay. And it would be meaningless to focus on gay/straight brains if you were a scientist from a (hypothetical) culture in which divisions of gender and sexual orientation did not exist or did not matter.

Size of structures, moreover, must be defined: where do you measure from? Many structures in the brain do not have clearly defined boundaries separating them - at least to the untrained eye. So before measurements are possible, there has to be consensus about what defines the boundaries of (say) nuclei in the hypothalamus; where do clusters of one type of cell stop and the next start? Similarly, much of the criticism levied against studies reporting gender differences in the corpus callosum (the bands of nerve fibres connecting the two hemispheres of the brain) has centred on discrepancies in what was being measured (Gallo and Robinson, 2000). Anne Fausto-Sterling, analysing scientists' attempts to map the corpus callosum (CC), notes that 'the neuroscientist who wants to study the CC must first tame it turn it into a tractable, observable, discrete laboratory object ... But ... this process fundamentally alters the object of study' (Fausto-Sterling, 2000: 120-1).

Not only does extracting and fixing brain tissue forever change it, but measuring three-dimensional structures is tricky. One lab may measure a swelling in the bulbs of the corpus callosum in a different place or way than another lab; one scientist may see significance in one axis of measurement and another see none. In other words, how you read the images you produce is crucial to the findings.

These issues are central to analysing LeVay's study. What he produced in the paper were photomicrographs of thin slices of tissue taken from the hypothalamus of the sampled brains. To most people, these seem to be little more than a random pattern of dots (the nerve cells) and a few interconnecting squiggles (the nerve axons). It is then a leap of imagination to see in these squiggles and dots an area that can be defined as larger in one brain than another. What is significant is that the reader of a scientific article is indeed expected to make that 'leap of imagination': that is crucially part of the rhetoric of science.

The photographs help to 'frame' the phenomenon (difference in brain cells), and thus to define it; once described in this way it is no longer a specific photograph of cells from one specific brain, but must be generalised to constitute 'the' homosexual brain. What are, in practice, possible differences in degree (quantitative differences in the volume of this area of brain) become categorised as differences of type (qualitative differences) - simply because they are defined as 'belonging' to one category or another (gay vs. straight).

Whatever we might think about the search for some marker of homosexuality in the brain, that search relies on notions of brain organisation by hormones long before birth. In turn, that depends on concepts of control systems; implicit here is the idea that the control systems have somehow not worked quite right, their balance is awry. And it is that point that concerns me; while the argument that we are a bit different biologically can be - and has been-used to argue for tolerance, it can also imply that any kind of difference equals not-quite-fitting pathology. For what that can mean in turn is both biological justification for discrimination and for seeking medical 'cures' or 'preventions'. 
And it is us - the 'deviants' - whose bodies and lives are thus pathologised: there has been no search for the hormonal or genetic bases of queer-bashing.

\section{GENES AND EVOLUTION}

Another approach to seeking homosexuality 'in nature' is to look for patterns between individuals. Scientists might, for instance, look at patterns of homosexuality within families - one approach to asking whether homosexuality might be genetic. These questions gain new potency in the context of genetic manipulation and mapping, which might enable scientists precisely to pinpoint 'the' gene for homosexuality.

Another way of seeking patterns is to ask more general questions about what kinds of animals exhibit homosexual behaviour, and thus ask, how did homosexuality evolve in humans? Thinking about where species came from was altered dramatically and for ever in the nineteenth century by the idea of evolution. Rather than positing that a deity created all kinds of creature (including gay ones), evolutionary theory supposed that animals and plants evolved, through change, from earlier forms. Darwin suggested that this occurs through natural selection; that is, some individuals are able to survive better and so reproduce more successfully, passing on their traits to their offspring.

If species change over time, then how have particular forms evolved? In what ways are they adapted to their environments that allow them to survive? Ancestral giraffes, for example, must have included a few individuals with slightly longer necks; these were better able than their short-necked peers to get at nutritious vegetation higher up. So, they did better and left more offspring. Over time, more and more long-necked animals appeared - natural selection in operation. Similar arguments can be made about other types of organism; how have they evolved?

Inevitably, given the notion of 'the' homosexual as a type, ${ }^{14}$ evolutionary theorists have asked about homosexuality (see Ruse, 1982). They start from the assumption that homosexuals generally have fewer offspring; if so, how could homosexuality evolve? Any genes that favoured it ought, the theory goes, to disappear over time as they confer no reproductive advantage. ${ }^{15}$

Homosexuality, then, is like altruism: both present problems to the serious Darwinian theorist, because neither apparently immediately enhance the individual's chances of surviving to reproduce. ${ }^{16}$ Homosexuality may be explained in various ways within the theory (see Ruse, 1982, 1988) but all confront the same problem, that homosexuality is neither unitary nor unchanging through history. So just what, exactly, is it that theorists are trying to explain? Merely having a tendency towards homosexuality could be completely ineffective in bringing about evolutionary change - you could have that tendency and still be married and reproduce heterosexually (as many women have had to do throughout history).

Whichever explanation might be favoured, modern evolutionary theories require genetics. Although Darwin had pondered how traits might be inherited, the idea of 'the gene' developed later, from the beginning of the twentieth century. Gradually, it came to represent not only an inheritable trait (like having blue eyes) but also a specific bit of the molecule of DNA (Gudding, 1996). Once the molecular structure of chromosomes was established (comprising centrally the double helix structure of DNA), scientists sought to 'map' the chromosomes, that is, to establish links between particular stretches of DNA and particular characteristics of an organism. Their ability to map chromosomes, took off, however, after scientists developed new methods for moving bits of DNA around ${ }^{17}$ - the basis of what is loosely called genetic engineering.

For much of the last century, however, studies claiming a genetic link to homosexuality were relatively rare (Allen, 1997). Indeed, it was not until the 1990s that genetic causes of homosexuality hit the 
headlines. First came studies reporting a greater than expected incidence of male homosexuality among identical twins ${ }^{18}$ (Bailey and Pillard, 1991; Pillard, 1997). The use of twins to infer inherited traits is controversial, and this was no exception (see Hubbard and Wald, 1993; Terry, 1997). Bailey and Pillard studied families with identical twins, non-identical twins and pairs of adoptive brothers, to see if there was correlation between degree of relatedness and homosexuality. If one brother of a pair was gay, and if the trait is substantially genetic, then you would expect to find that the other brother of identical twins is frequently also gay. This, Bailey and Pillard reported, was what they found: 52 per cent of their sample of 56 pairs of identical twins were both gay.

The twin study was quickly followed by Dean Hamer's report, widely publicised as identification of a 'gay gene'. What Hamer and his colleagues had done was to search for a genetic marker, that is, a particular stretch of DNA that might occur more often in homosexual men. Locating a genetic marker is not the same as identifying 'the' gene for something; it implies only that the scientists have found a bit of DNA that seems to be inherited along with the possible gene - like having a rainbow flag attached to your front door. So, if they are looking for a specific gene implicated in a particular genetic disease, they might identify a marker - a bit of DNA - that is close to the gene involved in the disease. By tracking the marker, ${ }^{19}$ they may learn more about the inheritance of the disease. Hamer's team looked specifically for markers on the $\mathrm{X}$ chromosome, which males inherit from their mothers. Again, they compared pairs of gay brothers to a group of unrelated men. For most such possible markers, there was very little similarity between the two brothers; but, for one tiny bit of DNA, called Xq28, DNA from the two brothers was very similar indeed - much more so than would be expected by chance. What this could mean is that Hamer's team had identified a marker which tends to be inherited more often than expected in homosexual brothers; the team were careful not to say that this was a cause although Hamer's later book (Hamer and Copeland, 1994) was subtitled 'The Search for the Gay Gene', so implying direct causation).

'Genes' are not, in practice, all that easy to locate on specific stretches of DNA, whatever we might suppose from media reports of 'new breakthroughs' in genetics. A few genes have been identified through their involvement in particular inherited diseases, such as cystic fibrosis. But much DNA is not so readily identified, and a great deal of it has no known function at present. ${ }^{20}$ If scientists move a piece of DNA, and the organism then develops a particular trait, they may not necessarily have moved the gene for that particular trait; many things might influence how a characteristic develops.

Claims that homosexuality is genetic have, however, faced problems from the belief that " "Animals don't do it, so why should we? ... If none of the lower orders engage in sex with the same gender, the motivating factor for homosexuality must not be genetic" (letter to Dean Hamer, quoted in Hamer and Copeland, 1994: 213). In other words, the writer of the letter believed that homosexuality is purely a human behaviour, not seen in any other species; if so, the writer implied, it could not be biological. Hamer's response to that accusation was to argue that animals are not good role models, even for heterosexuality (they don't date or frequent stripper bars, for example).

Another response, of course, is to point to the large number of examples of nonheterosexual behaviour among non-human animals. Bruce Bagemihl's recent book, Biological Exuberance (1999) reviews evidence for homosexual behaviour in a wide array of species-mammals and birds, particularly. Its significance, the cover blurb tells us, is that it is a book 'that definitively crushes the argument that homosexuality is not natural'.

Bagemihl draws upon a wide array of scientific studies which have noted (usually in passing or in a footnote) examples of animal behaviour that do not fit the standard model 
of reproductive heterosexuality. Needless to say, scientists who observed such behaviour, or the pairing of two animals of the same sex to hatch eggs ('lesbian gulls', for instance), have had a tough time; most commonly, they have tried to explain it all away (perhaps one of the animals is not really that sex? Perhaps there were no males around, so the gulls paired up to make the best of a bad job?). Or-of course!-perhaps one of the gulls is a bit too masculine.

A predominant narrative of modern biology is reproduction and the need to pass on the genes. Here, 'nature' is not so much red in tooth and claw (as the saying has it), as forever pregnant. Given that, it is hardly surprising that any non-procreative behaviour is simply not seen, or is classified as something else. So, if a female mammal licks the genitals of another female, or if one male sucks the penis of another, biologists are likely to interpret the behaviour as 'social'. 'Sex' is what happens when penises enter vaginas.

Bagemihl suggests otherwise. There are a plethora of examples of overt sexual practices (involving genital manipulation, say) between animals of the same sex, and many more examples of same-sex pairs engaging in rearing offspring, or maintaining lifelong affectional bonds (for a recent example, see Vasey et al., 1998).

Bagemihl compiled data for thousands of species, from a wide range of scientific sources. In that sense, his work has authority simply from the sheer volume of studies on which he draws, even if most of these do not overtly focus on homosexuality in their texts. I commented earlier on the need for students of science to learn 'how to see'. Like learning to see the photograph of hypothalamic cells, the observer of animal behaviour must learn to see or understand what animals do through the dominant set of ideas - in this case, the notion that reproductive success ensures the lineage of one's genes. Because of that, any form of nonreproductive behaviour may not be 'seen' as sexual by observing scientists.

Bagemihl's book, however, is aimed at a more popular audience. And it gains persuasive power for readers particularly through the use of photographs and line drawings, illustrating different kinds of animals engaging in various forms of non-procreative behaviour. ${ }^{21}$ So, we 'learn to see' homosexuality in nature, to interpret pictures as evidence of its existence. I emphasise this not because I necessarily doubt the pictures, but to stress that we, the readers, are collaborating in producing a story. In the case of this book, that story is about the prevalence of homosexuality in nature, but what does that mean for us?

\section{BIOLOGY AND HOMOSEXUALITY}

The last decade of the twentieth century was dubbed the Decade of the Brain; however, one might as well call it the decade of the Search for Homosexual Biology. ${ }^{22}$ The long quest continues, for instance, for hormonal causes; two recent instances concern lesbian ears (a study which claimed a difference between lesbian and heterosexual women in specific hearing tasks, McFadden et al., 1998), and our hands, shaped before birth by exposure to testosterone.

If the idea of a lesbian ear lends itself to jokes, then even more so for the idea of lesbian finger length (specifically, the ratio of length of first and third fingers; lesbians allegedly often have similar ratios to heterosexual men; Williams et al., 2000). In both cases, the researchers point out that the lesbian traits are similar to those of heterosexual men; hence, the argument goes, lesbians must have been masculinised before birth (the part of the brain involved in hearing, or our hands). Of course, the culprit has to be 'too much' testosterone-lesbians again becoming quasi-men.

So, yet again in the scientific literature, we who are lesbian or gay are cast as an 'intermediate' sex, we are mannish women or effeminate men. Sexuality is once again collapsed onto gender (or, rather, an assumed gender dichotomy), and the diversity of sexual and personal expression 
among our communities ignored. On the contrary, the biological theories, by basing themselves in binary assumptions, act to reinforce those assumptions of rigid gender divisions. And isn't that what we have been trying to move away from in recent years?

Nor does invoking biology get rid of that other prevalent notion that homosexuals are contagious. On the contrary, the genetic story reinvents contagion, through the reproductive narrative of 'spreading genes around'. And it is just that sense of contagion which shadows the new genetics and the notion of a 'gay gene'. For the stated remit of the Human Genome Project is the eradication of genetic diseases, by techniques of genetic engineering to remove problem genes (Bodmer and McKie, 1994). Locating a gene raises the spectre of prenatal diagnoses of 'homosexuality' in a foetus, and subsequent abortion. To be sure, some people may choose the other way, and try to have a foetus bearing the 'gay gene'. But in a largely homophobic society, there is a powerful danger of coercion to abort foetuses with the putative gene - not only because the parent does not want to raise a homosexual child (see Murphy, 1997), but also as a result of societal pressure to reduce the incidence of the gene (genetic contagion). In that sense, the rise of modern genetics has helped to reinforce the possibility of medical intervention.

The recent renaissance of biological theories about homosexuality has many sources. The AIDS epidemic (which facilitated the idea of contagion), the power of Christian fundamentalists in the USA (who believe we are all sinners), as well as the growing economic power of gay men - all these have contributed to this biological backlash against the social constructionism of the 1970s (Terry, 1997).

At the same time, there have been changes within biomedicine. One of these is that medicine no longer accepts degrees of intersexuality at birth; instead, newborns must be allocated to one or the other sex, and surgically altered to fit (see FaustoSterling, 2000). Not only does this reinforce binary assumptions about the sexed body, but it also reinforces assumptions that sex and sexuality reside in the body.

Alongside that, there has been intense effort to map and to manipulate genes, creating a climate in which 'the gene' is increasingly powerful, as well as fearprovoking (Turney, 1998). One consequence is that 'the gene' has become equivalent to identity, defining who we are (Nelkin and Lindee, 1995: 198). It is hardly surprising, in these changing contexts, that this powerful icon answers a need among some in our communities to find ways of explaining ourselves, to be able to say, 'it's not my fault'.

Jennifer Terry sees this surge of research, however, as a 'swan song of economically comfortable white men ... Maybe biology is a more comforting way to narrate their desires than to make sense of them in terms of cultural and historical contradictions, conflicts, and contingencies' (1997: 288). But, she points out, that claim has proved to be no help at all to troubled, young, working-class, men for whom the suggestion of an inbuilt, biological, trait can sometimes be 'one more reason to commit suicide rather than live in a world so hostile to their desires' (ibid.: 289, citing Acqueno, 1993). So, biology may indeed provide comfortable explanations for some; for others, it poses profound threats, with its implications that everything is fixed. Indeed, there is precious little evidence that alleged biological bases help stop bigotry; all kinds of people have been, and continue to be, persecuted because of their 'biology' (Hubbard and Wald, 1993; Stein, 1998).

Why do some among us so want to find scientific explanations? What is it about 'being homosexual' that requires explaining biologically in a way that 'being heterosexual' does not? We are, suggests historian of science Donna Haraway (1991), obsessed in Western culture with origin stories - tales of creation, of our roots. Seeking biological causes is but one version of that obsession, fuelled by the growing power of genetics. ${ }^{23}$ But the trouble with these stories is precisely that they suggest fixity. What worries critics 
of biological arguments is that, in such tales, we become little more than puppets on a string, acting out the dictates of DNA or hormones. Think about media representation of Hamer's experiments, for example. These very quickly became the discovery of 'the gay gene', reported as something which 'made us gay'. It is 'the' gene which has, uniquely, determined who we are.

But what seems to happen when critics reject biological determinism is that the pendulum swings over to emphasis on social constructionism (see Stein, 1992) - that we become gay through the way that society constructs notions of gender/sexuality. In this account, biology is largely irrelevant to our human development. Social constructionism has, moreover, been seized on by the religious right and interpreted as 'choice' (rather like consumer choice), and used as a justification for homophobia: if it is not biological, they argue, then it is a choice for sinning which we can, should we wish, correct. So, we can swing from theories of genetics to choice and back again either/or, take your pick.

It's a dilemma for any sociological reflection on who we are, not only for lesbian/ gay/transgendered people. Lesbian and gay studies, however, has generally had little to say specifically about biology. To be sure, it has addressed essentialism in general; some writers, such as Diana Fuss (1989), have argued, for example, for less polarity between essentialism and social constructionism. But the search for biological bases continues to maintain the binary, and continues to be insufficiently addressed in our academic inquiry. What is more, the stories of biological bases further perpetuate medical assumptions that gender and sexuality are themselves simple binaries, to be reinforced through surgical 'corrections' of newborns' genitals. Where do these assumptions leave those people who are born intersex?

Certainly, one way out of the dilemma of either biology or social constructionism is to look for ways of acknowledging biological factors without assuming them to be determining (eg. Benton, 1991; Rose, 1997; Birke, 1999). After all, biology must be involved in some ways: something affected the length of my fingers before I was born, whether or not that was lesbian hormones. It is precisely this that, I would argue, lesbian and gay studies needs to address in more detail, to ask the question: how might biology be relevant to our inquiries without invoking determism and fixity?

What is happening in the stories of genetic imperative, is that agency disappears. By that I mean not only conscious choices and decisions, but also the agency of our bodies; for example, as we grow from a fertilised egg, we change and engage with our own environment in bodily, biological ways. That process is partly biological, partly everything else, all interacting. It thus may be that biological processes are, in some ways, part of the events on the path leading to particular forms of expression of sexuality: but they do not determine. That is important to emphasise, partly because I think it is just a more accurate a way to think about biology - as potentially participatory and liberatory but not determining (see also Rose, 1997; Allen, 1997).

Yet could this help overcome the impasse between biological determinism and social constructionism? A number of biologists now seek to attack biological determinism by pointing to the complexity and subtlety of nature's processes. Evolution, for example, can act not only at the level of individuals and their genes, but also at the level of the group; organisms moreover can co-evolve, changing each other in the process. ${ }^{24}$ The task now for lesbian and gay theorists, then, is to find ways of bringing these ideas into our theory, to challenge determinist concepts of biology.

Among those who have emphasised complexity in nature and thus begun this task, is Bruce Bagemihl, in his narration of homosexual diversity among animals. He argues that the various expressions of sexuality and gender among other animals illustrates the extragavance, the exuberance, of biological systems (1999: 215). Like several other scientists, he draws on recent ideas about 
complexity and how order can arise out of (apparent) chaos (see Kaufman, 1995). While most of this scientific work remains far removed from lesbian and gay studies, its relevance here is that it makes room for understanding the world not as simple events (A causes B) but as multiple, complex and pluralistic. So, developing as a gendered individual is a product of many, layered and interacting processes. ${ }^{25}$

It seems to me that this vision of multiplicity fits our world of disparate sexualities and genders far, far, better than the predominant ideas drawn from science. Assuming that some people do want to ask questions about where sexualities come from, perhaps we donot have to choose between extremes of biological determinism and social constructionism, bouncing from one to the other like a pendulum. But we will not be able to find a middle ground if we cannot find ways of integrating a more liberatory understanding of biology. If we follow Bagemihl's lead, we can insist on different ways of understanding nature, ways that illustrate extravagance and pluralism. In that world, multiple sexualities are commonplace and there is no pressure (perhaps no need) to agonise over 'how we got to be that way'. But if ideas are going to be borrowed from biology, how much better that it is not the notion that we are all puppets on (genetic) strings. I would much rather be exuberant.

\section{NOTES}

1 Nelkin (1987) discusses media coverage of science and technology, asking not only how and why journalists cover particular stories but also how scientists themselves market their stories through press releases.

2 Nature/culture dualism has a long history, and has been much debated. See Soper (1995) and Horigan (1990) for discussion.

3 As I usually avoid ironing, I do find it irritating to come across the claim that females-liking-ironing is all down to biology. See Birke (1999). Am I a lesbian because I lack the crucial ironing genes?

4 There is some irony in this, given the way in which the clitoris was usually missing from anatomy textbooks: such omissions continue. See Moore and Clarke (1995).
5 Throughout the medical literature, sexual orientation is collapsed onto binaries of gender (feminine vs. masculine) and biological sex (male vs. female). No matter that none of these categories is absolutely dichotomous (not even biological sex); scientific accounts assume a simple binarism. Not only that, but they also assume that there is a simple relationship between each binary category. Femme lesbians, masculine gay men, or any kind of transgender person, have no place here.

6 Reading existing social divisions onto nature reflects who gets to do science. Early in the Scientific Revolution, relations of gender and race became deeply embedded in the practices of science: its practitioners had to belong to certain categories of class, gender, sexuality. As Donna Haraway cogently observes, 'God forbid the experimental way of life have queer foundations' (Haraway, 1997: 30).

7 The discovery of oestrogens in the urine of that symbol of virile potency, the stallion, shook up previous simple assumptions, as did the discovery that androgens must often be converted into oestrogens in the body for them to have their 'masculine' effects: see Oudshoorn (1994).

8 This is doubtful; again, few behaviours in animals are the sole preserve of only one sex. It is also doubtful that hormones alone are responsible-the behaviour of other animals can affect how an animal grows up (see Birke, 1989).

9 Usually, this is beneficial; giving insulin injections to diabetic people helps to correct their internal feedback of blood sugar levels, for example. But it does open up possibilities of less ethical interventions, such as giving a child a drug to inhibit growth hormone if $\mathrm{s} / \mathrm{he}$ is growing 'too much'. Here, too, the drug is one which affects feedback controls.

10 The Interstitial Nucleus of the Anterior Hypothalamus. The hypothalamus is organised into various areas, or nuclei, which seem to have slightly different functions within the brain.

11 Speculations about the biological roots of human behaviour always trap themselves in the quagmire of animal examples. But we cannot ever study animal societies without bringing to bear our own cultural expectations; as Donna Haraway (1989) notes, the history of our closest relatives, the other primates, is also a history of how gender, race and colonialism have been read onto nature. The example of 'homosexual rats' is just another instance of ways in which the production of ideas in science emerges from a particular culture and historical moment. 'Homosexual rats' are deviant rats; and they are deviant because they have been defined as such through a process of labelling hormones, bodies and brains as dualistically gendered.

12 Female rats only usually accept male mounting when they are in heat (oestrus), but not at other times. And contrary to assumptions that this is purely passive, female rats tend to control much of the encounter.

13 One of the many criticisms of LeVay's study has been that he could never know whether any of the bodies had been exclusively gay or straight people. His samples came from bodies of people who had died of AIDS; his 
classification of 'gay' relied on personal disclosure in medical records, that HIV had been transmitted through homosexual sex. But what if that had been a relatively rare gay encounter, in an otherwise 'heterosexual' life?

14 Interestingly, Morris (1993), in his examination of the work of Oscar Wilde, suggests that it was not ideas of natural selection so much as concepts of Victorian degeneracy which led to anti-gay legislation, directed against a specific type of person. This was, he argues, part of a late nineteenth-century reaction against the implications (for the nuclear family) of Darwinian natural selection.

15 Note that this argument is meant to apply to change over evolutionary time - many millennia. It is only very recently that humans have been able to separate sex and reproduction fairly effectively, and to develop specific forms of reproductive technologies. There has not been enough time for that to exert any impact on evolution.

16 Altruism is usually explained by supposing that it has evolved as a form of helping your relatives (with whom you share genes). But that theory does not explain the recent observation that chimpanzee males tend to form co-operative groups of unrelated males: Mitani et al. (2000).

17 This required new methods, developed in the 1970 s and $1980 \mathrm{~s}$, of amplifying tiny fragments of DNA, as well as new techniques for 'snipping' the molecule in specific places.

18 Identical (monozygotic) twins have more-or-less identical DNA. Non-identical twins (dizygotic) have 50 per cent of their DNA in common, as do other siblings or parent and child.

19 That is, scientists can track the patterns of DNA in tissue samples taken from members of different generations of a family.

20 Such pieces are called 'junk DNA', because they have no purpose (yet) known to scientists.

21 Greg Myers (1990) notes how the persuasive power of drawings and photographs is enhanced through the interpretive work readers of popular scientific texts must do-reconstructing the story that the pictures of animals, and accompanying text, set up.

22 It is the specific focus on homosexuality in the research that concerns me. Perhaps we do need more research on sex, as Dean Hamer and Peter Copeland urge (1994: 220-1), especially as so many lives have been lost to AIDS. But there remains a dearth of research on sexuality: it is we, the deviants, who are always the focus.

23 Significantly, modern narratives of genetics embody many themes of creation drawn from our Judaeo-Christian heritage: see Newman (1995) for discussion.

24 For many years, the notion of group selection was discredited; many evolutionary theorists, however, now believe that evolution operates through many different mechanisms simultaneously, including selection at the level of the whole population. See Rose (1997).

25 Anne Fausto-Sterling (2000) argues for an understanding of multiple sexes, based on her analysis of the complex processes involved in creating sexed bodies. It is a cultural conceit that we demand only two, she points out, and that generates much suffering as people are forced into binary straitjackets.

\section{REFERENCES}

Acqueno, F. (1993) Remarks at Out/Write Conference on Lesbian and Gay Writing and Publishing, Boston, MA (cited by Terry, 1997).

Allen, G.E. (1997) 'The double-edged sword of genetic determinism: social and political agends in genetic studies of homosexuality, 1940-1994', in V.A. Rosario (ed.), Science and Homosexualities. London: Routledge.

Bagemihl, B. (1999) Biological Exuberance: Animal Homosexuality and Natural Diversity. London: Profile Books.

Bailey, J.M. and Pillard, R.C. (1991) 'A genetic study of male sexual orientation', Archives of General Psychiatry, 48: 1089-96.

Barale, M.A. (1991) 'Below the belt: (un)covering the Well of Loneliness', in D. Fuss (ed.), Inside/Out: Lesbian Theories, Gay Theories. London: Routledge.

Benton, T. (1991) 'Biology and social science: why the return of the repressed should be given a (cautious) welcome', Sociology, 25: 1-29.

Birke, L. (1989) 'How do gender differences in behavior develop? A reanalysis of the role of early experience', in P. Bateson and P. Klopfer (eds), Perspectives in Ethology, Vol 8: Whither Ethology? New York: Plenum Press.

Birke, L. (1999) Feminism and the Biological Body. Edinburgh: Edinburgh University Press.

Boclmec, W. and Mckie, R. (1994) The Book of Man: The Guest to discover our genetic Heritage. London: Little brown.

Butler, J. (1993) Bodies that Matter: On the Discursive Limits of 'Sex'. London: Routledge.

Byne, W. and Parsons, B. (1993) 'Human sexual orientation: the biologic theories reappraised', Archives of General Psychiatry, 50: 228-39.

Dorner, G. (1976) Hormones and Brain Differentiation. Amsterdam: Elsevier.

Fausto-Sterling, A. (1997) 'How to build a man' in V.A. Rosario (ed.), Science and Homosexualities. London: Routledge.

Fausto-Sterling, A. (2000) Sexing the Body: Gender Politics and the Construction of Sexuality. New York: Basic Books.

Fuss, D. (1989) Essentially Speaking: Feminism, Nature and Difference. London: Routledge.

Gallo, V. and Robinson, P. (2000) 'Is there a "homosexual brain"?' Gay and Lesbian Review, Winter: 12-15.

Genova, J. (1989) 'Women and the mismeasure of thought', in N. Tuana (ed.), in Feminism and Science. Bloomington, IN: University of Indiana Press. 
Gibson, M. (1997) 'Clitoral corruption: body metaphors and American doctors' constructions of female homosexuality, 1870-1900' in V.A. Rosario (ed.), Science and Homosexualities. London: Routledge.

Gross, A.G. (1990) The Rhetoric of Science. Cambridge, MA: Harvard University Press.

Gudding, G. (1996) 'The phenotype/genotype distinction', Journal of the History of Ideas, 57: 525-45.

Hall, D.L. (1975) 'The critic and the advocate: contrasting British views on the state of endocrinology in the early 1920s', Journal of the History of Biology, 9: 269-85.

Hamer, D. and Copeland, P. (1994) The Science of Desire: The Search for the Gay Gene and the Biology of Behavior. New York: Simon and Schuster.

Hamer, D.H., Hu, S., Magnuson, V.L., Hu, N. and Pattatuchhi, A.M.L. (1993) 'A linkage between DNA markers on the $\mathrm{X}$ chromosome and male sexual orientation', Science, 261: 321-7.

Haraway, D. (1989) Primate Visions: Gender, Race and Nature in the World of Modern Science. London: Routledge.

Haraway, D. (1991) The contest for primate nature: daughters of Man-the-Hunter in the field. In D. Haraway, Simians, Cyborgs and Women: the Reinvention of Nature. London: Routledge. pp. 81-108.

Haraway, D. (1997) Modest_Witness@Second_ Millennium: FemaleMan meets OncoMouse. London: Routledge.

Highfield, R. (1995) “"Gay Gene” found in fruit flies', Electronic Telegraph, 6 June.

Horigan, S. (1990) Nature and Culture in Western Discourses. London: Routledge.

Hubbard, R. and Wald, E. (1993) Exploding the Gene Myth, Boston, MA: Beacon Books.

Kauffman, S. (1995) At Home in the Universe: The Search for the Laws of Complexity. Harmondsworth: Penguin.

Keller, E.F. (1996) 'The biological gaze' in G. Robertson, M. Mash, L. Tickner, J. Bird, B. Curtis and T. Putnam (eds), FutureNatural: Nature/Science/Culture. London: Routledge.

Kennedy, H. (1997) 'Karl Heinrich Ulrichs, first theorist of homosexuality', in V.A. Rosario (ed.), Science and Homosexualities. London: Routledge.

Knorr-Cetina, K. (1983) The ethnographic study of scientific work: towards a constructionist interpretation of science. In K Knorr-Cetina and M. Mulkay (eds), Science observed: Perspectives on the Social Study of Science. London: Sage.

Latour, B. (1987) Science in Action. Buckingham: Open University Press.

LeVay, S. (1991) 'A difference in hypothalamic structure between heterosexual and homosexual men', Science, 253: 1034-7.

LeVay, S. (1993) The Sexual Brain. Cambridge, MA: MIT Press.

Lynch, M. (1990) 'The externalized retina: selection and mathematicization in the visual documentation of objects in the life sciences', in M. Lynch and S. Woolgar (eds), Representation in Scientific Practice. Cambridge, MA: MIT Press.

McFadden, D. and Pasanen, E. (1998) 'Comparisons of the auditory systems of heterosexuals and homosexuals: click-evoked otoacoustic emissions', Proceedings of the National Academy of Sciences, 95: 2709-13.

Mitani, J.C., Merriweather, D.A. and Zhang, C. (2000) 'Male affiliation, cooperation and kinship in wild chimpanzees', Animal Behaviour, 59: 885-93.

Moore, L.J. and Clarke, A.E. (1995) 'Clitoral conventions and transgressions: graphic representations in anatomy texts, c1900-1991', Feminist Studies, 21: 255-301.

Morris, A.R. (1993) 'Oscar Wilde and the eclipse of Darwinism: aestheticism, degeneration, and moral reaction in late-Victorian ideology', Studies in History and Philosophy of Science, 24: 513-40.

Murphy, T.F. (1997) Gay Science: The Ethics of Sexual Orientation Research. New York: Columbia University Press.

Myers, G. (1990) 'Every picture tells a story: illustrations in E.O. Wilson's Sociobiology', in M. Lynch and S. Woolgar (eds), Representation in Scientific Practice. Cambridge, MA: MIT Press.

Nelkin, D. (1987) Selling Science: How the Press Covers Science and Technology. New York: W.H. Freeman and Company.

Nelkin, D. and Lindee, M.S. (1995) The DNA Mystique: The Gene as a Cultural Icon. New York: W.H. Freeman and Company.

Newman, S. (1995) 'Carnal boundaries: the commingling of flesh in theory and practice', in L. Birke and R. Hubbard (eds), Reinventing Biology. Bloomington: University of Indiana Press.

Oudshoorn, N. (1994) Beyond the Natural Body: An Archeology of Sex Hormones. London: Routledge.

Pillard, R.C. (1997) 'The search for a genetic influence on sexual orientation', in V.A. Rosario (ed.), Science and Homosexualities. London: Routledge.

Rosario, V.A. (ed.) (1997) Science and Homosexualities. London: Routledge.

Rose, S. (1997) Lifelines: Biology, Freedom, Determinism. Harmondsworth: Penguin.

Rosenberg, R. (1982) Beyond Separate Spheres: Intellectual Roots of Modern Feminism. New Haven, CT: Yale University Press.

Ruse, M. (1982) 'Are there gay genes? Sociobiology and homosexuality', in N. Koertge (ed.), Philosophy and Homosexuality. New York: Harrington Park Press.

Ruse, M. (1988) Homosexuality. Oxford: Basil Blackwell. Schiebinger, L. (1994) Nature's Body: Sexual Politics and the Making of Modern Science. Boston: Beacon Books.

Soper, K. (1995) What is Nature? Oxford: Blackwell.

Spanier, B. (1995) Im/Partial Science: Gender Ideology in Molecular Biology. Bloomington, IN: Indiana University Press.

Stein, E. (ed.) (1992) Forms of Desire: Sexual Orientation and the Social Constructionist Controversy. London: Routledge. 
Stein, E. (1998) 'Choosing the sexual orientation of children', Bioethics, 12: 3-24.

Terry, J. (1997) 'The seductive power of science in the making of deviant subjectivity', in V.A. Rosario (ed.), Science and Homosexualities. London: Routledge.

Terry, J. (1999) An American Obsession: Science, Medicine and Homosexuality in Modern Society. Chicago: University of Chicago Press.

Turney, J. (1998) Frankenstein's Footsteps: Science, Genetics and Popular Culture. New Haven, CT: Yale University Press.

Vasey, P.L., Chapais, B. and Gauthier, C. (1998) 'Mounting interactions between female Japanese
Macaques: testing the influence of dominance and aggression', Ethology, 104: 387-98.

Wijngaard, M.v.d. (1997) Reinventing the Sexes: The Biomedical Construction of Femininity and Masculinity. Bloomington, IN: Indiana University Press.

Williams, T.J., Pepitone, M.E., Christensen, S.E., Cooke, B.M., Huberman, A.D., Breedlove, N.J., Breedlove, T.J., Jordan, C.L. and Breedlove, S.M. (2000) 'Fingerlength ratios and sexual orientation', Nature, 404: 455-6. 